Article available at http://wWw.parasite-10urnal.org or http://dx.doi.org/10.1051/parasite/200108s2144

\title{
DIAGNOSIS OF HUMAN TRICHINELLOSIS: PITFALLS IN THE USE OF A UNIQUE IMMUNOSEROLOGICAL TECHNIQUE
}

\author{
COSTANTINO S.N.*, MALMASSARI S.L.*, DALLA FONTANA M.L.*, DIAMANTE M.A.* \& VENTURIELLO S.M.*
}

\section{Summary :}

Serum samples belonging to three outbreaks in Argentina (47 patients) taken at different times post-ingestion were analysed employing IIF and ELISA simultaneously. Results show that: a) the number of patients diagnosed by a unique technique, especially by ELISA (31 patients), was lower than the one obtained by the simultaneous use of both assays (38 patients); b) four patients out of the seven diagnosed by a unique technique were negative by the other assay over the period of time evaluated. Therefore, it can be concluded that the use of a sole immunoserological technique can not only lead to the delay in the detection but also to the misdiagnosis of this parasitic infection.

KEY WORDS : immunodiagnosis, human trichinellosis, ELISA, indirect immunofluorescense.

A lthough the diagnosis of human trichinellosis depends on a combination of epidemiological anamnesis, clinical signs and symptoms and laboratory tests, the detection of specific host antibodies (Abs) are commonly the only reliable diagnostic procedure. The most widely employed techniques for detection of human trichinellosis in epidemic outbreaks are the indirect immunofluorescense test (IIF) (Ljungström, 1974; Ruitenberg, 1975; Coltorti, 1981) and ELISA (Ljungström, 1983; Gamble, 1983; Chapa-Ruiz, 1990). However, the possibility that serology detects the early phase of infection, time at which an antiparasite treatment would be most effective, is not always possible due in part to inherent characteristics of the techniques employed. Taking this into account, the aim of this work was to assess the possibility of achieving an early diagnosis of the infection employing two techniques simultaneously which use different antigens (Ags).

\footnotetext{
* Institute of Humoral Immunity Studies, CONICET, Faculty of Pharmacy and Biochemistry, University of Buenos Aires, Junín 956, 1113 Buenos Aires, Argentina.

Tel.: (54-11) 4964-8260 - Fax: (54-11) 4964-0024.

E-mail: sventuri@ffyb.uba.ar
}

\section{MATERIALS AND METHODS}

HUMAN SERA

erum samples from 47 patients belonging to three outbreaks, arisen in different areas in Argentina, were taken at 14,21, 30 and 40 days post-ingestion (dpi) and analyzed.

\section{INDIRECT IMMUNOFLUORESCENCE TEST}

Human sera were analyzed by IIF using cryostat sections of Trichinella spiralis muscle larvae (ML) as $\mathrm{Ag}$ (Coltorti, 1981). Briefly, sections were incubated for $30 \mathrm{~min}$ at $37^{\circ} \mathrm{C}$ with $30 \mu \mathrm{l}$ of sera diluted $1 / 64$ in phosphate-buffered saline solution (PBS). After washing three times with PBS plus $0.05 \%$ Tween 20 (PBS-T), samples were incubated for $30 \mathrm{~min}$ at $37^{\circ} \mathrm{C}$ with $30 \mu \mathrm{l}$ of anti-human gammaglobulin rabbit serum conjugated to fluorescein isothiocyanate (Diagnostic Pasteur) diluted 1/50 in Evans blue. After washing, sections were mounted in buffered glycerine solution and examined by fluorescence microscopy (Zeiss). Fluorescence in the larval cuticle and internal structures was considered a positive reaction.

\section{ELISA}

Serum samples were also analyzed by indirect ELISA. Briefly, flat-bottomed PolySorp polyvinyl microtiter plates (Nunc) were coated with $50 \mu \mathrm{l} /$ well of $\mathrm{ML}$ excretory-secretory products (ML-ESP), obtained as previously described (Gamble, 1983), at a concentration of $5 \mu \mathrm{g} / \mathrm{ml}$ in carbonate buffer $\mathrm{pH} 9.6$ during one hour at $37^{\circ} \mathrm{C}$ and overnight at $4^{\circ} \mathrm{C}$. After coating, and between each step, plates were washed three times with PBS-T. Plates were then blocked using $3 \%$ nonfat dry milk in PBS for one hour at $37^{\circ} \mathrm{C}$. Serum samples were tested diluted $1 / 200$ in PBS-T plus $0.3 \%$ non-fat dry milk (dilution buffer). After incubating one hour at $37^{\circ} \mathrm{C}$ a horseradish peroxidase-conjugated anti-human IgG serum (Diagnostic Pasteur) diluted $1 / 2000$ in dilution buffer was added and incubated for another hour at $37^{\circ} \mathrm{C}$. Colour reaction was developed 


\begin{tabular}{|c|c|c|c|c|c|c|}
\hline \multirow[b]{2}{*}{ Outbreak $\mathbf{N}^{\circ}$} & \multirow[b]{2}{*}{ Technique } & \multicolumn{5}{|c|}{ Number of diagnosed patients } \\
\hline & & $14 \mathrm{dpi}$ & $21 \mathrm{dpi}$ & $30 \mathrm{dpi}$ & $40 \mathrm{dpi}$ & Total \\
\hline \multirow{3}{*}{$\begin{array}{c}\mathrm{I} \\
(\mathrm{n}: 17)\end{array}$} & IIF & 3 & 7 & 0 & 0 & 10 \\
\hline & ELISA & 2 & 6 & 0 & 0 & 8 \\
\hline & IIF and/or ELISA & 4 & 7 & 0 & 0 & 11 \\
\hline \multirow{3}{*}{$\begin{array}{c}\text { II } \\
(\mathrm{n}: 17)\end{array}$} & IIF & NA & 8 & 7 & 0 & 15 \\
\hline & ELISA & NA & 8 & 4 & 0 & 12 \\
\hline & IIF and/or ELISA & NA & 8 & 7 & 0 & 15 \\
\hline \multirow{3}{*}{$\begin{array}{c}\text { III } \\
(\mathrm{n}: 17)\end{array}$} & IIF & NA & 11 & 0 & 0 & 11 \\
\hline & ELISA & NA & 10 & 0 & 1 & 11 \\
\hline & IIF and/or ELISA & NA & 11 & 0 & 1 & 12 \\
\hline $\begin{array}{c}I+I I+I I I \\
(n: 47)\end{array}$ & IIF and/or ELISA & 4 & 26 & 7 & 1 & 38 \\
\hline
\end{tabular}

NA: sera not available.

Table I. - Number of patients diagnosed by a unique and/or both immunoserological assays at different days post-ingestion.

using $0.004 \% \mathrm{w} / \mathrm{v}$ o-phenilendiamine (Sigma) and $0.004 \% \mathrm{v} / \mathrm{v} \mathrm{H}_{2} \mathrm{O}_{2}$ in citrate buffer $\mathrm{pH}$ 5.0. Reaction was stopped by addition of $50 \mu \mathrm{l} 4 \mathrm{~N} \mathrm{H}_{2} \mathrm{SO}_{4}$ and optical densities (OD) read at $490 \mathrm{~nm}$ in an ELISA reader (Metertech 5960). The cut-off OD, previously calculated for this reaction, was 0.400 .

\section{RESULTS}

T Thirty-eight out of the 47 analyzed patients could be diagnosed during the period of evaluation. Four out of the 17 patients evaluated at $14 \mathrm{dpi}$ rendered positive results at least by one immunoserological technique (one by ELISA, two by IIF, one by ELISA and IIF). Out of the remaining 43 individuals evaluated, 26 rendered positive results at $21 \mathrm{dpi}$ (one by IIF, 25 by ELISA and IIF), seven were diagnosed at $30 \mathrm{dpi}$ (three by IIF, four by ELISA and IIF), one was diagnosed at $40 \mathrm{dpi}$ (by ELISA) and nine were negative over the period of time evaluated.

Seven patients were diagnosed by a unique technique (two by ELISA, five by IIF): three of them rendered positive results by the other assay while the remaining four individuals persisted seronegative over the followup period.

The number of patients diagnosed by a unique technique, especially by ELISA (31 patients), was lower than the one obtained by the simultaneous use of both assays (38 patients).

These results are shown in Table I.

\section{DISCUSSION}

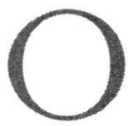
ur results show that the simultaneous use of two immunoserological techniques which use different Ags allows the achievement of an ear- lier diagnosis than the one obtained by the use of a unique technique, allowing the establishment of a more effective antiparasite treatment. Besides these results reinforce the importance of a serological followup in those individuals whose clinical and/or epidemiological histories make them suspicious of being infected by this parasite.

The advantage of achieving an early detection of the infection could not be ascribed to a particular technique, showing individual features in the immune response generated in each host-parasite relationship mainly at the onset of the infection, since specific Abs can be detected by both techniques by $30 \mathrm{dpi}$ in most of the patients. However in some individuals, Abs could be detected by only one technique meaning that the simultaneous use of these two methodologies has the additional advantage of a reduced probability of misdiagnosis of this parasite infection.

\section{ACKNOWLEDGEMENTS}

T his work was supported by grants from the Buenos Aires University and National Research Council. The authors thank all involved professionals and patients for their cooperation.

\section{REFERENCES}

Chapa-Ruiz M.R., Salinas Tobon M.R. \& Garcia-Latorre E. Recognition of Trichinella spiralis muscle larvae antigens by sera from humans infected with this parasite and its potential use in diagnosis. Bulletin de la Societé Française de Parasitologie, 1990, 8, 951-954.

COLTORTI E.A. Evaluación de la inmunofluorescencia indirecta en el diagnóstico y la seroepidemiología de la triquinosis humana. Acta Bioquimica Clínica Latinoamericana, 1981, 15, 599-607. 
Gamble H.R., Anderson W.R., Graham C.E. \& Murrell K.D. Diagnosis of swine trichinosis by enzyme-linked immunosorbent assay (ELISA) using an excretory-secretory antigen. Veterinary Parasitology, 1983, 13, 349-361.

Ljungström I. Antibody response to Trichinella spiralis, in: Trichinellosis. Kim C.W. (ed), Intext Educational Publishers, New York, 1974, 449-460.

LJUNGSTRÖM I. Immunodiagnosis in man, in: Trichinella and trichinosis. Campbell W.C. (ed), Plenum Press, New York, 1983, 403-424.

Ruitenberg E.J., Ljungström I., Steerenberg A. \& Buys J. Application of immunofluorescence and immunoenzyme methods in the serodiagnosis of $T$. spiralis infection. Annual New York Academy Science, 1975, 254, 296-303. 